\title{
SERUM PROTEINS IN DIABETIC ACIDOSIS
}

\author{
By JOHN P. PETERS, DAVID M. KYDD AND ANNA J. EISENMAN
}

(From the Department of Internal Medicine of Yale University and the Medical Service of the New Haven Hospital, New Haven)

(Received for publication November 4, 1932)

It has been demonstrated that in diabetic acidosis the serum proteins $(1,2,3)$, hemoglobin and blood cell volume $(1,2)$ are usually normal or high, falling with recovery from the acute condition. This has been interpreted as an indication that the blood is inspissated in acidosis, and becomes diluted again during recovery. This conception has received support from direct blood volume studies made by the carbon monoxide method by Chang and Harrop (4). In general it has been assumed that the hemoconcentration of acidosis is related to general body water depletion. In the present study, by comparison of serum proteins with other chemical constituents of the blood and with clinical features of the condition, an attempt has been made to test this conclusion and to evaluate the importance of hemoconcentration and general body fluid loss in diabetic acidosis.

\section{MATERIAL AND METHODS}

The methods of chemical analysis employed have been described frequently in other papers from this department (5). Altogether 53 cases of diabetic acidosis have been studied. Of these 12 died. Death was in no case referable to uncomplicated diabetes. The patients who died had pneumonia, septicemia or cerebral hemorrhage and these associated conditions seemed to play a predominant role in determining their fatal endings. Total serum proteins were determined 117 times in 32 cases; protein fractions 54 times in 15 cases. In most instances the total acidbase equilibrium of the serum was determined simultaneously and in some cases the cell volume and oxygen capacity of the blood as well. Studies were made on admission and at varying intervals during the subsequent course in the hospital.

\section{General level and course of serum proteins}

During the acute stage of diabetic acidosis the serum proteins are usually normal, sometimes distinctly above normal. During recovery they decrease rapidly. This fall in proteins seems to be related to clinical improvement. It does not, however, cease with the termination of symp- 
toms and signs of acidosis, but continues for a few days beyond the recovery period. The most obvious explanation for both the initial high protein concentration and the subsequent fall is changes in serum water content.

The reductions of serum protein during recovery are, in some cases, so great that one hesitates to refer them entirely to restoration of the normal serum volume without confirmatory evidence, especially since the lowest values reached are always below, of ten far below, normal serum protein concentrations. Obviously, there is actual depletion of serum proteins before, during, or immediately after the acidosis. If the fall during recovery is referable only to restoration of serum volume, it is to be presumed that the protein depletion preceded or accompanied the development of acidosis, perhaps as a result of malnutrition. In Figure 1 serum

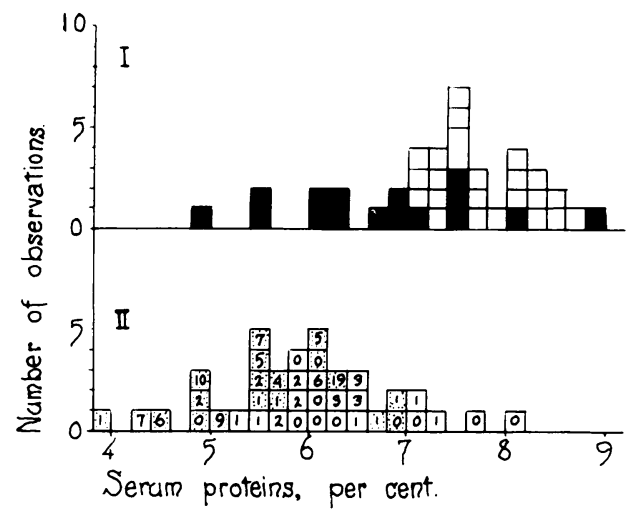

Fig. 1. The Relation of Serum Protein Concentration to the Nutritional State

In I are shown initial observations at the height of acidosis. Solid squares represent emaciated subjects.

In II are shown subsequent observations. Stippled squares represent emaciated subjects, the small numerals in the squares the number of days since admission. $O$ indicates the time between admission and $7: 00 \mathrm{~A} . \mathrm{M}$. of the following morning and is usually less than 24 hours.

protein concentrations at the height of acidosis are compared with the nutritive states of the patients. Proteins below 7 per cent were observed only in emaciated subjects. In the second part of the figure the lowest protein value observed during recovery is compared in the same manner with the nutritive state. Again the lowest values are found chiefly among the emaciated. The line of demarcation between the two groups is, however, no more sharp,--perhaps less sharp, than in the preceding figure. A partial explanation for this lack of differentiation can be found in the duration of the period of treatment which is indicated by the numerals in the squares. In four of the emaciated subjects with proteins above 
6 per cent, observations were made within 24 hours or less of the time of admission, which experience has shown is long before the protein fall is completed. Another was examined on the 19 th day, when the return to the normal level is usually well advanced.

It seems reasonable, then, to ascribe the hypoproteinemia of the recovery period in part, at least, to malnutrition which preceded the development of acidosis. This is especially true of the extreme protein reductions. This explanation is further supported by the parallel rise of proteins and weight with later improvement in nutrition. It is, however, quite apparent from the second figure that the proteins fall to or below the minimum normal level, 6 per cent, even in apparently well nourished subjects. If these reductions are also to be ascribed to malnutrition, one must conclude that a relatively short period of acute starvation can check the production or cause the destruction of serum proteins far more seriously than can a more prolonged chronic undernutrition. It may be objected that there is no evidence that these diabetic subjects had normal serum proteins before the onset of the acidosis. There is, of course, no direct evidence on this subject. However, in previous studies (1), which have now been supplemented by further data, it was found that the serum proteins of well nourished diabetics without complicating conditions lay within normal limits. The weight losses during the development of acidosis are, of course, enormous; but the greater part of these losses probably consists of body fluids, not proteins. Albuminuria, although frequent, is not a constant finding and is seldom extreme except for a short period at the height of acidosis when the urine volume is usually small. Loss of proteins from the blood stream through the capillary walls may explain certain acute drops which will be discussed later, but can hardly explain persistent low values.

It is conceivable that hemodilution for some reason proceeds beyond restoration of the normal blood volume during the recovery period. It has long been recognized that at this time some diabetic subjects develop frank edema, while a far greater number gain weight rapidly for a few days, only to lose a large proportion of it later or to maintain a steady weight for a considerable interval. Such gains are evidently due to water accumulation and in the most extreme examples are associated with low serum proteins $(6,7)$. More moderate temporary increases, seldom resulting in visible edema, are seen, however, in subjects with normal serum protein concentration, suggesting that some factor other than hypoproteinuria, in this condition, may determine the accumulation in the body of excessive quantities of water and salt. Unequivocal evidence of such transient accumulations were observed on only 8 occasions in this series out of 25 in which adequate data were secured. In only 2 instances did frank edema develop.

Figure 2 illustrates the course of the serum proteins during recovery 
from acidosis. Cases have been selected in which determinations were made after the first 48 hours. The extremely rapid initial drop and the subsequent slower decline can be seen in some of the cases, as well as the

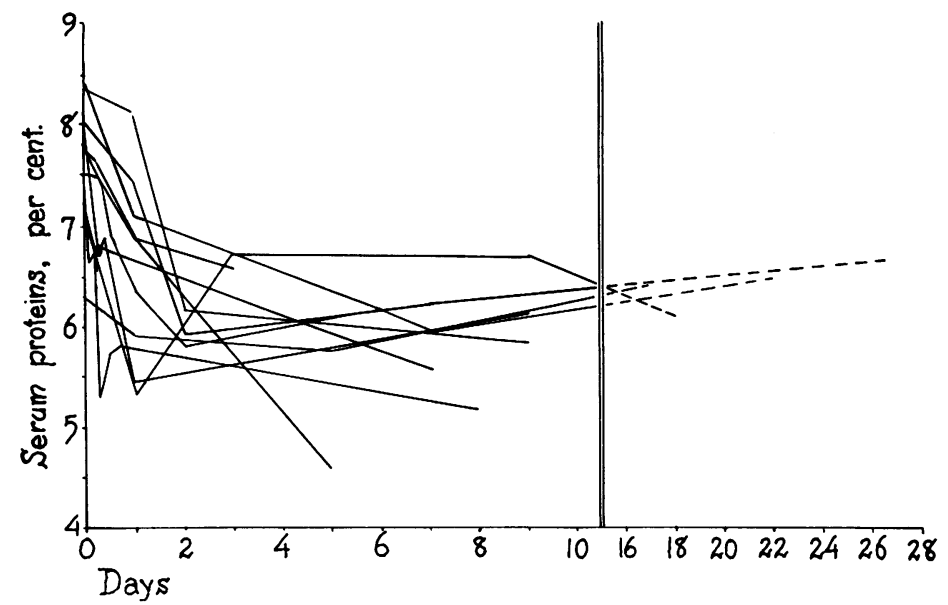

Fig. 2. The Course of the Serum Proteins during Recovery From Diabetic ACIDOSIS

gradual rise that attends return to normal nutrition. In Figure 3 serum proteins are compared with body weights of the two subjects who developed edema. The protein figures in the first case give no indication of
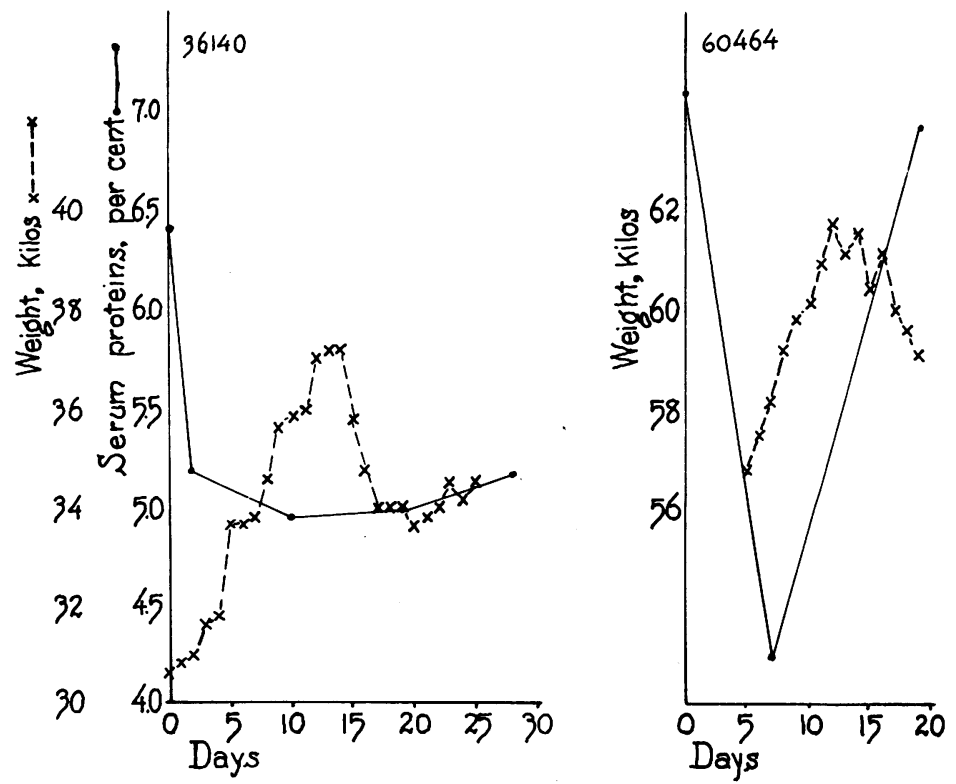

Fig. 3. The Course of the Serum Proteins and Body Weight during Recovery from Diabetic Acidosis in 2 Patients Who Developed EDEma. 
serum dilution during the edematous period. While the edema was rapidly accumulating the proteins were 4.95 per cent. Immediately after the completion of diuresis they were 4.98 per cent, an insignificant change. In the second case the extremely low figure during the development of edema and the subsequent rise are more suggestive of hemodilution. The levels of serum proteins in these cases are about the same as those seen in patients with diabetes who develop edema without any acute antecedent acidosis $(7,8)$.

Although the latter case may leave a reasonable suspicion that excessive accumulations of fluid after recovery from acidosis may be associated with temporary hemodilution and that this may partly explain the hypoproteinemia, this evidence is negatived by the fact that reductions of protein of lesser degree, but still below the normal level, were observed in the larger proportion of patients who showed no signs of excessive fluid retention. Moreover, the protein deficiency which developed affected the albumin fraction of the proteins chiefly or entirely, as one would expect in malnutrition, whereas hemodilution should affect albumin and globulin fractions equally.

\section{Serum proteins and hemoconcentration}

In a certain proportion of cases, besides total serum proteins, protein fractions, blood cell volume, or oxygen capacity were determined. The changes in these variables have been compared with the changes in total proteins in Figures 4 and 5. In both figures only relative values are given, initial values being taken as 100 per cent and subsequent values being compared with these on the assumption that changes in concentration of any of the components considered are referable entirely to changes in blood or serum volume. In the case of the proteins, the protein fractions and the oxygen capacity, these subsequent values are secured by dividing the value observed on a given day by that found at the initial examination.

In Figure 4 the solid lines and dots represent serum volumes estimated in this manner from total proteins alone. The circles connected by dots and dashes represent blood volume estimated in the same way from oxygen capacity alone. It has been demonstrated by Chang and Harrop (4) and others (1) that although cells are less affected than plasma by the changes of blood concentration, they do not escape entirely Changes in the size and water concentration of cells may be expected if the acid-base or osmotic equilibrium of the serum is disturbed. Under these circumstances blood volume and plasma volume will not parallel one another, although they may vary in the same direction. If it be assumed, for the purposes of comparison, that the total number of cells in circulation re- 
mains constant, relative plasma volumes may be estimated from oxygen capacity and cell volume by the formula:

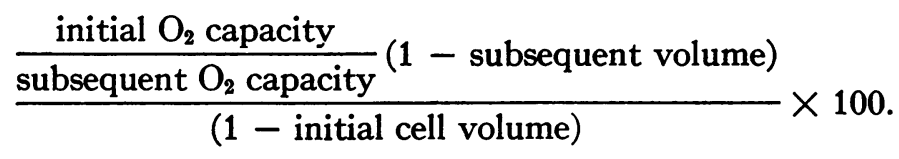

The crosses connected by broken lines represent plasma volumes estimated in this manner, except in cases 36140, $22350 \mathrm{I}, 81042,48711$ and 82331.

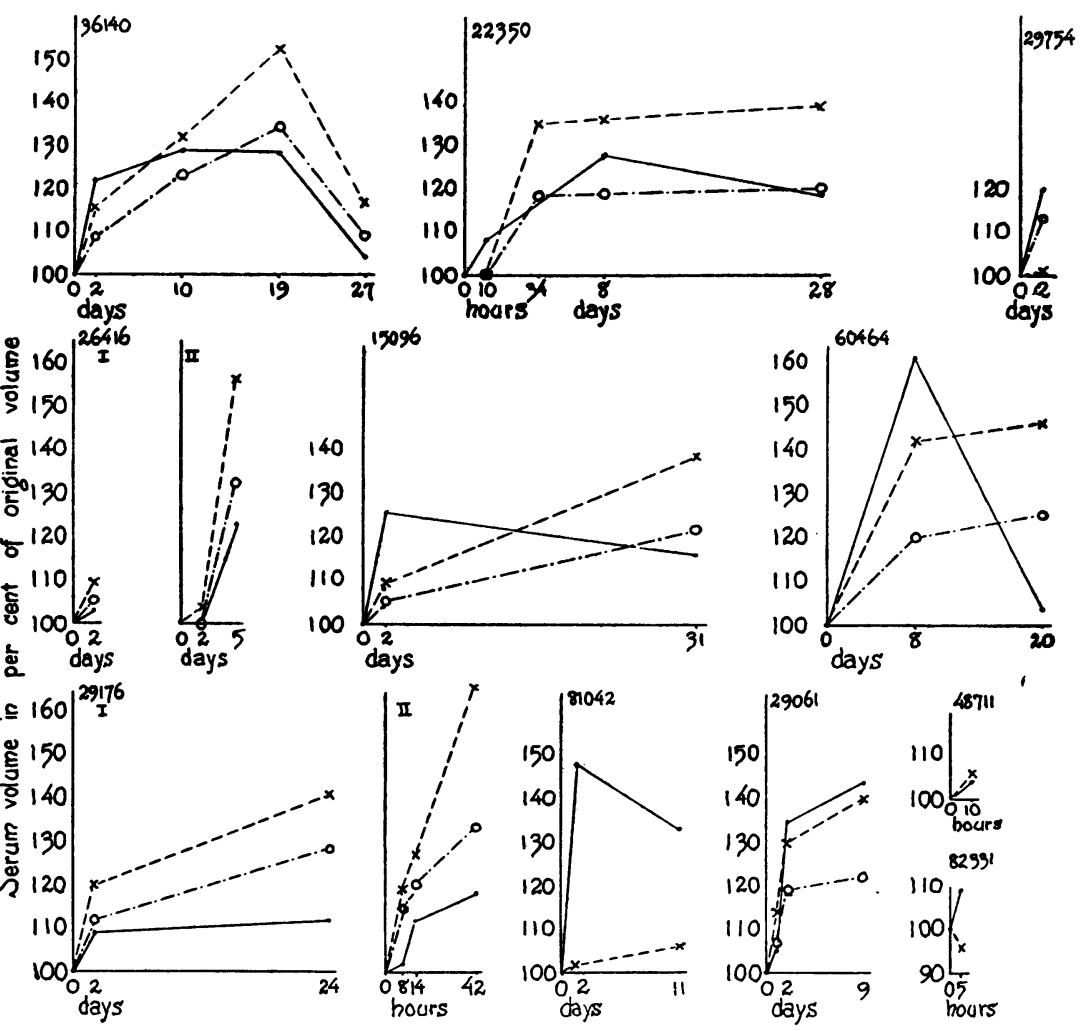

Fig. 4. Serum Volume Changes during Recovery from Diabetic Acidosis Estimated from Serum Proteins - - · and from Oxygen Capacity and Cell Volume Together $x---x$, as well as Blood Dilution CalcuLaTed From OXYGen Capacity Alone o- - 0 .

Ordinates represent values of serum and blood volume expressed in per cent of initial volume. Abscissae represent time. For methods of calculation see text.

Cell volumes were determined on only one occasion in 36140 and $22350 \mathrm{I}$. Subsequent cell volumes were estimated with the assumption that the amount of hemoglobin per unit of cell volume remained unchanged. In cases 81042, 48711 and 82331 oxygen capacity was not determined. 
Therefore the broken lines and crosses represent blood volume changes estimated from cell volume data alone.

It is at once evident that in all but one case blood volume and plasma volume rise together, of ten to a surprisingly great degree, during recovery
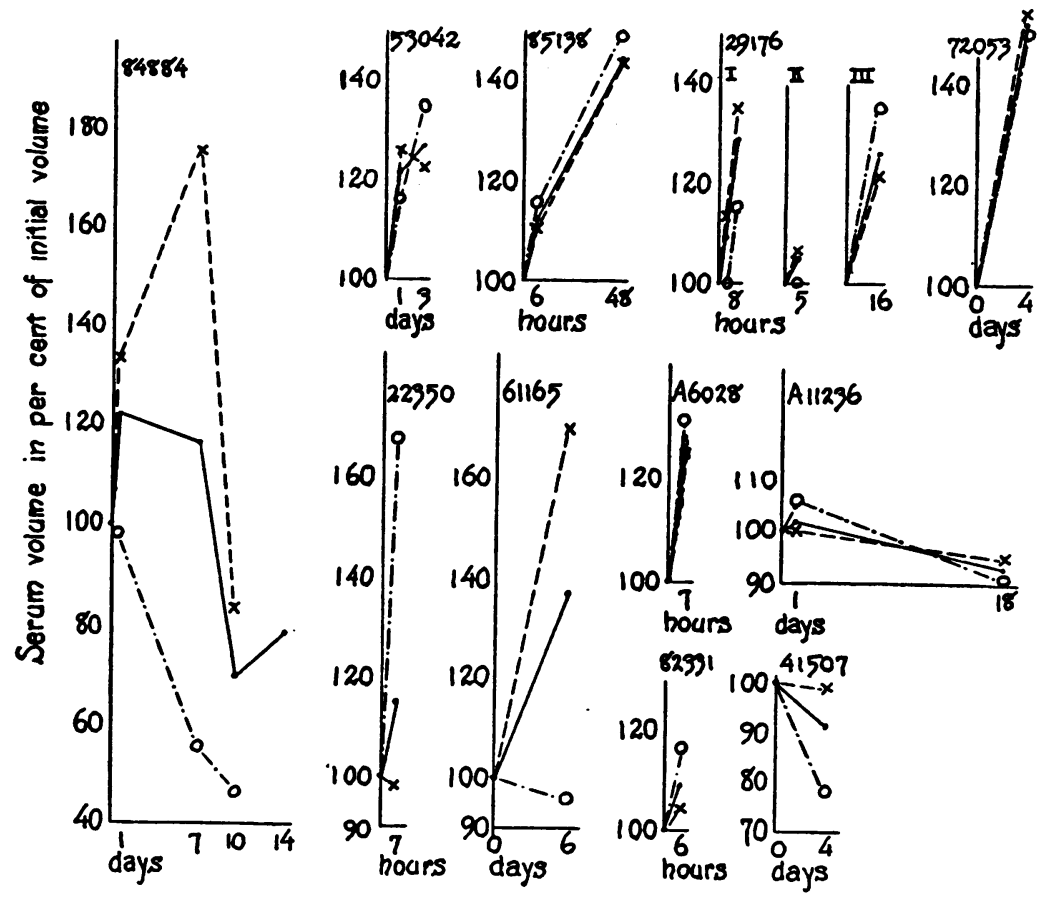

Fig. 5. Serum Volume Changes during Recovery from Diabetic Acidosis Estimated from Total Serum Proteins --·, Serum Albumin $x---x$ and Serum Globulin o-- 0 .

Ordinates represent values of serum volume in per cent of initial volume. Abscissae represent time.

from acidosis, and that this hemodilution increases for some days. In the one exception, 82331, at the time of the second study the blood pressure had fallen suddenly, probably as a result of insulin shock. This may well have caused a temporary disturbance of the distribution of red blood cells in the circulation or have permitted transitory loss of protein from the blood stream. Although oxygen capacity, cell volume and serum proteins all change in the same direction, the magnitude of the changes in the different components is extremely variable. It has already been pointed out that parallelism between oxygen capcaity and proteins is not to be expected. The parallelism between serum volume changes calculated from proteins and from oxygen capacity and cell volume together is, however, no better. The authors are inclined to believe that the directional parallelism is sufficient evidence that the chief changes are referable 
to hemodilution. The deviations of the three curves may well be due to circulatory disturbances, similar to that mentioned above, which alter the distribution of cells in the blood stream.

Support for this view is found in the general tendency shown in Figure 5 for total protein, albumin and globulin to vary together. There are three distinct exceptions. Case 84884 had anuria for 5 days, with a gastro-intestinal condition that prevented the administration of oral fluids. Her curves can not, therefore, be considered simply as those of recovery from diabetic acidosis. The sudden paradoxical change in the proportions of albumin and globulin in 22350 II strongly suggests an analytical error. Case 61165 in the 6 day interval between blood studies developed an acute cystitis, which may have been responsible for the unexpected rise of globulin. In this figure, as in the other, it is clear that the hemodilution of recovery, if the data are to be so interpreted, continues for some days.

It has already been pointed out that in most instances the proteins ultimately reach subnormal levels, from which they gradually rise during convalescence, with improvement of nutrition. Although, during the initial fall, the protein fractions drop together as one would expect if the decline was due to hemodilution, at the low point globulin is seldom below the normal limits; albumin alone is depleted, as is usually the case in malnutrition.

\section{The lack of relation between hemoconcentration and body fluid changes}

If the reductions of serum protein that occur during the recovery from diabetic acidosis are to be ascribed to restoration of the normal plasma volume, which seems the most logical deduction from these data and from the direct blood volume studies of Chang and Harrop (4), it is evident that the initial hemoconcentration must be quite extreme, entailing losses of 20 or 30 per cent or more of the plasma fluid at times. It seems not entirely probable that such losses of blood water are always paralleled by proportional losses from the fluid supplies of the body or even from the extracellular fraction of those fluid supplies. It seems more likely that the depletion of plasma fluid in diabetic acidosis is only partly related to the general desiccation that results from diuresis, overventilation, vomiting and other phenomena of the condition. There is probably in addition loss of fluid from the blood stream to the tissues.

The lack of relationship between serum concentration and body water is illustrated in Figure 6. In this figure the rate of fluid intake is plotted against the rate of serum dilution. There is no demonstrable statistical relation between the two variables. There seems to be a general tendency for the serum to remain concentrated throughout the first periods of treatment in spite of the administration of large amounts of fluid, to become diluted later even when only small amounts are given. It does not 
seem possible to attribute this lag in expansion entirely to delay in absorption of fluids, because the latter, in the initial stages of treatment, were usually given subcutaneously or intravenously and because simultaneous electrolyte determinations reveal changes in the salt concentration in the serum that could only come from absorption of these fluids. Nor can it be attributed entirely to the more rapid expenditure of fluids

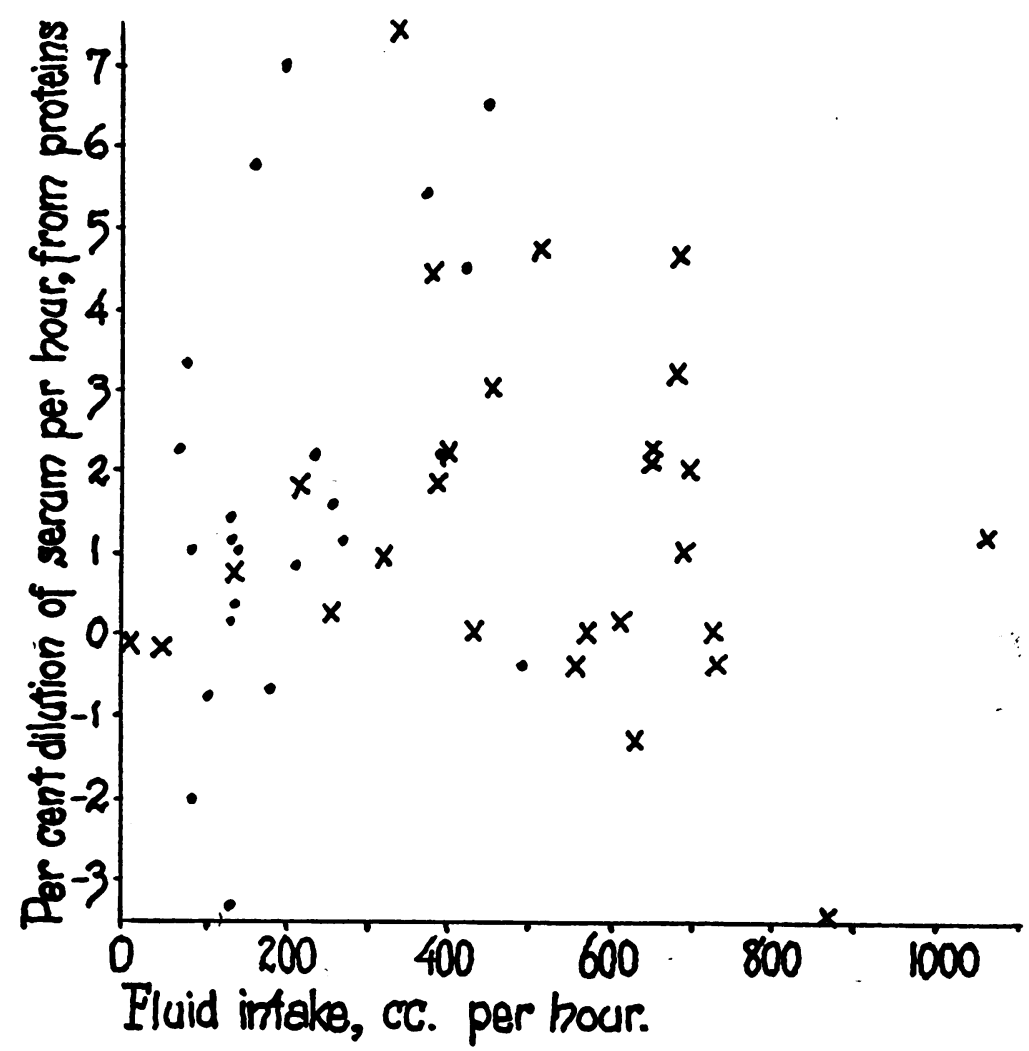

Fig. 6. Serum Volume Changes Compared with Fluid Intakes during Recovery from Diabetic Acidosis

Ordinates represent changes of serum volume per hour calculated from serum protein changes, expressed in per cent of initial serum volume. Abscissa represent fluid intake per hour. Crosses indicate initial periods of study, dots subsequent periods.

in the earlier periods. In some instances in which the serum proteins had fallen inappreciably at the onset when fluid retention was large, they dropped quite precipitously later when the fluid balance was frankly negative. In general, although initial failure to dilute the serum seemed to be connected with no particular disorder of the chemical composition of the serum, it occurred usually in those patients who were most seriously 
TABLE 1

Data in illustrative cases

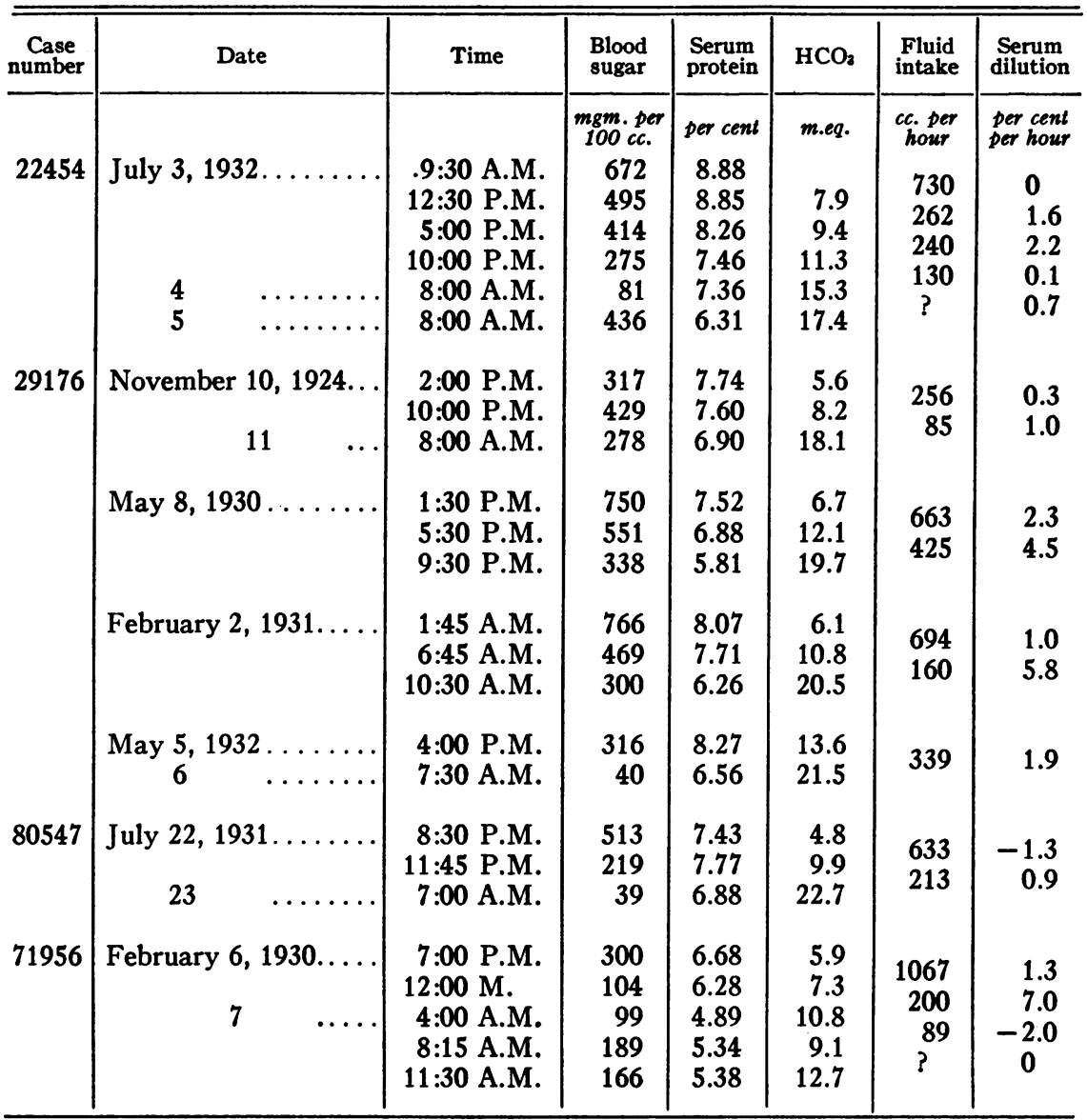

ill. Furthermore, subsequent failure to dilute, or reappearance of hemoconcentration, betokened a change for the worse in the clinical condition. These points can be more clearly demonstrated by consideration of certain illustrative cases, the relevant data of which are shown in Table 1. (Protocols of these cases may be found at the end of the article.)

The first four cases in the table, 22454, 29176, 80547 and 71956, illustrate the general tendency for blood dilution to lag for some hours after admission, even when carbohydrate combustion has begun and bicarbonate is rising. None of these subjects presented complications which could account for the persistent hemoconcentration. In 22454 the lag of 3 hours occurred during a period in which large amounts of fluid were given subcutaneously and were apparently absorbed with rapidity. In the second and third periods there is increasingly rapid hemodilution during 
TABLE 1 (continued)

\begin{tabular}{|c|c|c|c|c|c|c|c|}
\hline $\begin{array}{c}\text { Case } \\
\text { number }\end{array}$ & Date & Time & $\begin{array}{l}\text { Blood } \\
\text { sugar }\end{array}$ & $\begin{array}{l}\text { Serum } \\
\text { protein }\end{array}$ & $\mathrm{HCO}_{3}$ & $\begin{array}{c}\text { Fluid } \\
\text { intake }\end{array}$ & $\begin{array}{c}\text { Serum } \\
\text { dilution }\end{array}$ \\
\hline & & & $\begin{array}{l}\text { mgm. per } \\
100 \text { cc. }\end{array}$ & per cent & m.eq. & $\begin{array}{l}\text { cc. per } \\
\text { hour }\end{array}$ & $\begin{array}{l}\text { per cent } \\
\text { per hour }\end{array}$ \\
\hline \multirow[t]{3}{*}{48711} & October $8,1929$. & $\begin{array}{l}\text { 10:00 A.M. } \\
\text { 3:00 P.M. } \\
\text { 8:00 P.M. }\end{array}$ & $\begin{array}{l}396 \\
274 \\
187\end{array}$ & $\begin{array}{l}8.44 \\
8.53 \\
8.08\end{array}$ & $\begin{array}{r}6.2 \\
10.8 \\
13.8\end{array}$ & $\begin{array}{r}48 \\
142\end{array}$ & $\begin{array}{r}-0.2 \\
1.0\end{array}$ \\
\hline & May $19,1930$. & $\begin{array}{l}\text { 3:00 P.M. } \\
\text { 7:30 P.M. }\end{array}$ & $\begin{array}{l}353 \\
254\end{array}$ & $\begin{array}{l}8.16 \\
8.23\end{array}$ & $\begin{array}{r}9.2 \\
12.2\end{array}$ & 22 & -0.2 \\
\hline & 20 & 8:10 A.M. & & $\begin{array}{l}0.20 \\
7.22\end{array}$ & 17.6 & 136 & 1.2 \\
\hline \multirow[t]{2}{*}{72053} & November 25,1928 . & 5:00 P.M. & 399 & 7.67 & 4.2 & 433 & 0 \\
\hline & 26 & 8:50 A.M. & $\begin{array}{l}285 \\
167\end{array}$ & $\begin{array}{l}7.07 \\
6.93\end{array}$ & $\begin{array}{r}7.0 \\
15.3\end{array}$ & 274 & 1.2 \\
\hline \multirow[t]{2}{*}{22074} & January $12,1929$. & $\begin{array}{r}11: 00 \text { A.M. } \\
2: 30 \text { P.M. }\end{array}$ & $\begin{array}{r}1240 \\
780\end{array}$ & $\begin{array}{l}7.54 \\
8.54\end{array}$ & $\begin{array}{l}5.5 \\
8.9\end{array}$ & 864 & -3.4 \\
\hline & 13 & 12:30 A.M. & 352 & $\begin{array}{l}0.04 \\
7.00\end{array}$ & $\begin{array}{r}0.7 \\
18.8\end{array}$ & 398 & 2.2 \\
\hline \multirow[t]{3}{*}{81042} & September $20,1929 \ldots$ & 11:30 P.M. & 346 & 8.09 & 5.5 & 380 & 4.4 \\
\hline & 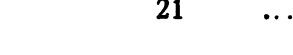 & $\begin{array}{l}\text { 4:00 A.M. } \\
\text { 8:00 A.M. }\end{array}$ & $\begin{array}{l}315 \\
253\end{array}$ & $\begin{array}{l}6.72 \\
6.92\end{array}$ & $\begin{array}{l}11.3 \\
16.4\end{array}$ & 103 & -0.8 \\
\hline & 22 & 8:30 A.M. & 297 & 5.48 & 24.2 & ? & 0.7 \\
\hline \multirow[t]{3}{*}{15670} & September $27,1929 \ldots$ & 4:00 A.M. & 500 & 7.82 & 4.7 & 400 & 2.2 \\
\hline & & $\begin{array}{l}\text { 9:00 A.M. } \\
\text { 12:00 N. }\end{array}$ & $\begin{array}{l}360 \\
140\end{array}$ & $\begin{array}{l}7.04 \\
7.87\end{array}$ & $\begin{array}{r}8.2 \\
13.0\end{array}$ & 133 & -3.3 \\
\hline & & 3:00 P.M. & 134 & 7.18 & 15.5 & 77 & 3.3 \\
\hline
\end{tabular}

the oral administration of diminishing quantities of fluid. During the fourth period dilution is almost checked, but the rate of fluid administration is quite small. Moreover, during this period there may have been mild insulin shock. The second case shows the reactions of the same individual on four different occasions, but differences in treatment make comparison difficult. At the first admission when he was most seriously ill and symptoms persisted longest, there was no appreciable hemodilution for $\mathbf{8}$ hours. Comparison with the second and third periods, in which the serum proteins fell more rapidly when he was less seriously ill, is difficult, because fluids on these two admissions were administered so much more rapidly. On the last admission, when he came in before the acidosis was severe, the time interval between the only 2 determinations is so long that the course of serum dilution can not be traced. In 80547 there is an exaggeration of the initial lag sufficient to cause a transient increase of serum proteins with subsequent dilution when the fluid intake is slower. In spite of the low blood sugar of 39 at 7:00 A. M. July 23d, she presented no signs nor symptoms of insulin shock. In 71956 there is again a slow initial dilution with a subsequent rapid fall of proteins. The rate of fluid administration during the first period was greater in this case than in any 
other. The slight concentration during the third period may be referable to the low rate of fluid administration. However, it is equally possible that there had been excessive dilution during the third period, because the serum proteins after the fourth period seem to have attained a constant level.

Case 48711 received fluid more slowly than any other patient. This may, in part, but not entirely, explain the delayed, slow dilution. During the first admission in the 10 hours of the study, she received only $950 \mathrm{cc}$. of fluid and excreted in vomitus and urine $655 \mathrm{cc}$. leaving a total positive balance of only $300 \mathrm{cc}$. to provide for both the insensible perspiration and expansion of the serum. There can, therefore, have been little or no actual increase of body fluids, but only a redistribution by which the serum profited at the expense of the extravascular fluids. In certain of the preceding cases, also, fluid excretion so closely approaches intake that the increases of serum water must have come largely from intrinsic supplies. For example, 29176 received 2050 and $850 \mathrm{cc}$. and excreted 350 and 1820 cc. in the two periods of his November 1924 admission, respectively, leaving a total positive fluid balance of only $730 \mathrm{cc}$. for 18 hours in which the serum proteins fell from 7.74 to 6.90 , denoting a 12 per cent expansion of serum volume.

All the data suggest that during the development and the severe stages of acidosis there is not only a general depletion of the body water stores, but also a more particular loss of fluid from the blood stream and that the process of recovery involves in part the restoration of the serum fluid volume. Although this can not be effected in the most advanced cases without the administration of fluid, replenishing the body water does not in itself insure restoration of the serum volume. To a certain extent the serum volume and body water act as independent variables.

\section{Shock as a cause of hemoconcentration}

From the examples, which have been given, of the conditions under which hemoconcentration has been observed, it seems probable that circulatory failure, and especially peripheral stasis or shock, are responsible for the escape of fluid from the circulatory system or its failure to remain in or return to the vascular bed. In the cases which have been cited it is quite evident that such circulatory failure can develop or increase even when carbohydrate combustion is proceeding in a satisfactory manner and serum $\mathrm{CO}_{2}$ is rising. This is more clearly illustrated by the last four cases of Table 1 .

Case 72053, towards the end of the first period, which lasted over 6 hours, developed distinct signs of circulatory failure with auricular fibrillation, and dilution did not begin until the circulatory condition had improved. Case 22074 is the only fatal case in this series. His condition was complicated by lobar pneumonia. On admission he had evidences of 
profound circulatory failure which did not improve until the second period. During this initial period of shock the serum became more concentrated in spite of a high rate of fluid administration. The later dilution attended a period of temporary improvement.

Finally, in 81042 and 15670 satisfactory dilution during initial periods was followed by temporary increases of serum proteins which accompanied the development of transient mild symptoms of shock associated with falling blood pressure. Such symptoms of shock, coming on during recovery from acidosis, have been observed not infrequently. It was, at first, believed that they were associated with critical falls of blood sugar and might be akin to insulin shock. However, such an explanation can hardly answer in the case of 81042 who had no striking fall of blood sugar during the whole period of investigation.

Clinically, hemodilution seems to mark improvement, delay in restoration of serum volume and hemoconcentration are associated with continuation or increase of symptoms and, in this respect, are more accurate criteria for prognosis than either blood sugar or $\mathrm{CO}_{2}$. Case 71956, for example, at the time of the third blood examination was free from symptoms with a bicarbonate of only 10.8 m.eq., lower than that which 29176 presented at the time of the fourth admission. Case 15670 was in a quite precarious situation at 12 noon when his blood sugar was only 140 and the bicarbonate 13 m.eq.

How serious this shock syndrome may become and how favorably it is influenced by anti shock measures is illustrated by cases A-11236, 60464, A-700 and 82685, whose protocols appear at the end of the article. All these patients presented obvious signs of profound circulatory failure, usually with low or falling blood pressures. When the circulatory function improved under therapeutic influences, especially intravenous infusion or blood transfusion, the clinical improvement was of ten dramatic.

In case 82685 , who died in the most profound shock, during the early stages serum proteins rose from 7.28 to 7.43 per cent indicating hemoconcentration. Later, when the systolic blood pressure fell to $\mathbf{5 0}$ the proteins dropped to 5.96 per cent. This is the only instance in this series of cases in which the development of shock was associated with a fall of serum proteins. It seems hardly probable that this fall indicates serum dilution. It is more likely that it denotes advance of shock to the point where the vessel walls permitted protein to escape from the blood stream.

Blood transfusion was employed as an emergency measure in 9 cases. Of these 4 died. Although some serious contributory disease was always partly responsible for the fatal issue, profound shock or circulatory failure always preceded death and seemed to be precipitated by the diabetic acidosis. Lawrence (14) has also recognized the importance of circulatory failure as a cause of mortality. Even in the fatal cases transfusion had some transitory beneficial effect, which was evidenced not only by 
circulatory improvement, but also by amelioration of the mental condition and accelerated disappearance of those clinical and functional disturbances that were even more directly referable to the diabetes, especially the dyspnea. The improvement in mental condition and respiration was especially noticeable in cases A-11236 and 60464, who recovered. Similar improvement was observed in cases in which shock responded to other measures than transfusion.

\section{Shock as the cause of symptoms in diabetic acidosis}

The term "shock" has, perhaps, been employed rather loosely throughout this paper to describe a condition in which the circulating blood volume is diminished and the blood pressure is below the normal level. Among the phenomena that have been recognized as characteristic of shock is the tendency for fluids to pass from the vessels into the tissue spaces. In milder forms of shock the transudate appears to be relatively free from protein, indicating that the normal semi-permeability of the capillary walls with respect to protein is retained. In the most severe grades this impermeability is lost and proteins pass with the fluids from the blood stream (9). Both phenomena have been demonstrated in the cases reported.

The initial hemoconcentration appears to be only partly the result of general body water depletion, partly the result of transudation, probably related to phenomena associated with low blood pressure. Blalock (9) has demonstrated that a great variety of conditions that lower blood pressure cause such transudation. Certain experiments of Henderson and Haggard (11), the de Almeidas (12) and Dale and Evans (13) throw a light on the specific factors that may reduce the blood pressure in diabetic acidosis. Henderson and Haggard (11) found that, in dogs, prolonged excessive artificial ventilation not only lowered the carbon dioxide content of the blood, but also reduced the arterial blood pressure and induced a syndrome similar to that of traumatic shock, with coma among the symptoms. The de Almeidas (12) were unable to produce these symptoms by the same technique in the hot, humid climate of Rio de Janeiro unless the air was cooled and dried to atmospheric conditions resembling those in which Henderson and Haggard had worked in New Haven, Connecticut. They, therefore, concluded that overventilation shock was due chiefly to cooling and dehydration. Dale and Evans (13) found that when the blood pressure of narcotized cats had been lowered by overventilation, it could be restored to normal if the animals rebreathed previously expired air containing 4 to 5 per cent of $\mathrm{CO}_{2}$. It would, appear, then, that loss of $\mathrm{CO}_{2}$, cooling and dehydration are the factors which produce overventilation shock. The loss of $\mathrm{CO}_{2}$ in diabetic acidosis is not comparable to that in simple overventilation experiments. In the latter the loss of $\mathrm{CO}_{2}$ is the cause of alkalosis, in the former the result of 
acidosis. The cooling and dehydrating effects are, however, the same in either case. Additional causes of dehydration are, of course, found in diuresis as well as vomiting which so commonly accompanies the onset of acidosis.

The causes of the symptoms, and especially the coma, of diabetes have long been subjects of controversy. That, aside from the dyspnea, they are not due to reduction of serum bicarbonate and $\mathrm{pH}$ per se seems relatively certain from comparison with other conditions in which acidosis of equal severity is seen or has been produced. Peters, Wakeman, Eisenman and Lee (10) have reported a case of nephrosis whose serum bicarbonate was reduced to $4.3 \mathrm{~m}$. eq. by the administration of ammonium chloride with the production of no other symptoms than epigastric distress, nausea and vomiting. Similar cases have been reported by others. Although acetone and diacetic acid act as mild anesthetics, it has not been satisfactorily demonstrated that they accumulate in full anesthetic concentration in diabetics with acidosis. Furthermore, it has not been established that the depth of coma in diabetic acidosis is proportional to the degree of ketosis. If the latter can be judged by either the extent of the bicarbonate deficiency or the intensity of ketonuria, in this series, certainly, the state of consciousness bears no consistent relation to the ketosis. This is most clearly illustrated by the patients who continue stuporous or comatose after ketonuria has entirely cleared up and bicarbonate is well on its way to the normal level.

Such dissociation of the phenomena of diabetic acidosis could not be seen before insulin provided a means by which carbohydrate combustion could be rapidly reinstituted and ketosis as quickly abolished. Before insulin the attitude towards diabetic acidosis seems to have become so thoroughly fixed that the inconsistencies of the old point of view in the light of new material appear to have been overlooked. A striking instance of this dissociation is seen in the following case.

Case 82529, a female 24 years old, having abandoned insulin since Thanksgiving day of 1931 developed tonsillitis March 28, 1932. March 31 she vomited all food and fluids and was found to have profuse glycosuria. The next day vomiting continued and glycosuria increased. During the night of April 1 to 2 she went into deep coma and in this state was admitted to the hospital at noon on April 2. Meanwhile she had received at least 60 units of insulin in the preceding 24 hours, but had been entirely unable to retain fluids for 2 or 3 days. On admission she appeared well nourished, but extremely dehydrated and so stuporous that it was almost impossible to elicit any responses. The reflexes were almost abolished and her bladder was distended. The pulse was rapid, weak and irregular, the blood pressure 108/75. The respirations, however, were not exaggerated. The blood sugar was only $268 \mathrm{mgm}$. per $100 \mathrm{cc}$., the bicarbonate $12.8 \mathrm{~m}$.eq. and the first urine secured by catheter 
contained only traces of sugar and acetone. She was immediately given subcutaneously $1500 \mathrm{cc}$. of saline, followed in the next 3 hours by $1500 \mathrm{cc}$. of 5 per cent glucose and another $700 \mathrm{cc}$. of saline. Striking improvement, especially in the mental condition, followed the first saline injection. By 3:00 P. M. she took fluids freely by mouth. Further recovery was rapid and uneventful, although she remained somewhat drowsy and her heart action was occasionally weak and irregular for the first 12 hours.

This is only the most striking instance of a situation in which, by means of insulin, both ketosis and alkali deficiency have been largely eliminated, while depletion of body fluids and serum volume have persisted. The serum proteins on admission were 8.45 per cent, the next morning only 7.08, and by the morning of April 4th only 5.94. The stupor in this case can hardly have been referable to acidosis and ketosis. On admission the urine contained only traces of sugar and acetone, the blood sugar was at the moderate level of $268 \mathrm{mgm}$. per $100 \mathrm{cc}$. and serum bicarbonate 12.8 m.eq., a reduction not usually considered to be of dangerous significance. At 4:30 P. M., an hour and a half after she had begun to take fluids by mouth and was quite responsive, the serum bicarbonate was still at its original level and the blood sugar had actually risen to $314 \mathrm{mgm}$. Even by the next morning the bicarbonate was only 13.3 m.eq., although by this time the patient was completely rational, able to take food and fluids freely, with urine free from sugar and acetone and a blood sugar of $71 \mathrm{mgm}$. per $100 \mathrm{cc}$. The initial response to the parenteral administration of simple saline solution was quite impressive and elimination of symptoms appeared to be clearly referable to restoration of body fluids.

From such observations one is forced to the conclusion that even if ketosis can be a cause of the symptoms, and especially the mental disturbances of diabetic acidosis, it is not the sole cause. Reduction of serum volume, shock, is almost certainly a contributory factor. Alkali deficiency probably plays an indirect etiological role by producing both diuresis and overventilation.

If shock is so important a part of the syndrome of diabetic acidosis and a possible cause of both coma and death, it is obvious that restoration of blood volume as well as body fluids must be an important aim of treatment and that the course of the blood pressure gives information quite as significant as that contributed by determinations of blood sugar or serum bicarbonate. Furthermore, if the blood pressure is low or falling and fails to respond to the administration of carbohydrates, fluids, insulin and salt solution, blood transfusion may, as in other types of shock, be of the greatest value. 


\section{CONCLUSIONS}

1. In severe acidosis the serum proteins are usually within or above the normal limits, but fall, during recovery, below the normal level.

2. The initial high level seems to be due to hemoconcentration, the subsequent fall to restoration of normal serum volume.

3. Both the initial high levels and the later low levels seem to bear some relation to the state of nutrition, being lower in emaciated subjects.

4. The initial hemoconcentration is only partly due to depletion of body water, partly to loss of fluid from the vessels into the tissues. Restoration of serum volume is to a large extent independent of the replenishment of general body fluids.

5. When hemococentration and hypoproteinemia fail to respond to treatment, low blood pressure and signs of circulatory failure akin to shock are evident. Under these circumstances clinical symptoms, especially the mental state, do not improve.

6. Clinical improvement is better correlated with the changes in serum proteins than with blood sugar, serum bicarbonate or ketonuria.

7. It is suggested that the state of shock and its attendant hemoconcentration may be at least contributory causes of the coma of diabetic acidosis.

\section{PROTOCOLS}

Case 22454, female, 24 years old, with diabetes of 12 years' duration, treated with insulin for 9 years, had become somewhat careless in her treatment. July 1, 1932 she developed suddenly pain in her back and nausea with drowsiness. She omitted most of her insulin because she was unable to eat. July 2 air hunger began. At 2:30 A.M., July 3, the pain in the back became intense and persistent vomiting set in. On admission, at 9:30 A.M., she was semistuporous, but able to respond, dehydrated but not emaciated, overventilating greatly. By 1:30 P.M. she was breathing more quietly and taking fluids freely; by 5:00 P.M. the breathing was almost normal. Her subsequent recovery was uneventful and rapid except for unexplained backache that persisted 2 or 3 days. Her blood pressure on admission was 130/80.

Immediately after admission she received, subcutaneously, $1500 \mathrm{cc}$. of normal saline and $500 \mathrm{cc}$. of 5 per cent glucose solution. In addition to this she took during the first period of 3 hours, $1900 \mathrm{cc}$. of fluid by mouth. After this all fluids were given orally.

Case 29176, a male 36 years old, with diabetes of a year's duration and a previous admission in acidosis, discontinued insulin November 7,1924 . November 9 he felt so ill that he could eat no supper. At 3:00 A.M. November 10 he developed severe epigastric pain and persistent vomiting. On admission he was somewhat stuporous and irrational, emaciated and extremely dehydrated, with air hunger, slight cyanosis of the extremities, rapid thready pulse, a blood pressure of $112 / 85$, diff use tenderness and rigidity of the abdomen. Four hours later the abdominal symptoms had disappeared, but he was still overventilating, somewhat stuporous and irrational. After this, improvement was comparatively rapid and uneventful. In the first period of 8 hours he received, subcutaneously, $1000 \mathrm{cc}$. of saline and an equal amount of 5 per cent glucose solution; in the second period of 10 hours, he took by mouth $850 \mathrm{cc}$. of fluid. 
May 7, 1926, he omitted insulin and, during the following night, nausea, vomiting and epigastric pain set in. On the morning of May 8 he was given 20 units of insulin and at 1:30 P.M. was admitted to the hospital, semistuporous and overventilating, but without the abdominal signs and circulatory disturbances of the previous admission. Recovery was more rapid than on the previous occasion. During the first period of 4 hours he received, subcutaneously, $1500 \mathrm{cc}$. of saline containing 5 per cent glucose, and by mouth an additional 1350 cc. of fluid containing 5 grams of $\mathrm{NaCl}$ and 15 grams of sugar. During the second period of 4 hours he took $1700 \mathrm{cc}$. of fluid with 7.5 grams of $\mathrm{NaCl}$ and 40 grams of sugar.

He was readmitted February 2, 1931, under almost the same circumstances, having omitted insulin the preceding day. The condition on admission and the course of recovery were the same except that he vomited more than $900 \mathrm{cc}$. during the first period of 5 hours, in which he received, subcutaneously, $1500 \mathrm{cc}$. of saline and $500 \mathrm{cc}$. of 5 per cent glucose solution, with an additional $1500 \mathrm{cc}$. of water by mouth. During the second period of 4 hours he took, by mouth, $600 \mathrm{cc}$. of fluid with 35 grams of sugar, but no salt.

The last admission, May 5, 1932, differed from the others only in the fact that he came to the hospital before the acidosis had become so advanced. Recovery was proportionately accelerated.

Case 80547 , a female 28 years old with diabetes of two and a half years' duration, who had adhered to treatment carelessly for 2 years, began vomiting at intervals early in July 1931 . July 22 she omitted insulin entirely and began to vomit continuously. On admission, at 8:30 P.M. she was stuporous, overventilating, dehydrated, but not emaciated, with a temperature of $101.8^{\circ}$ F., pulse 120 , blood pressure $125 / 80$, and a greatly enlarged liver. Recovery was rapid and relatively uneventful. She received, in the first period of 3 hours, subcutaneously, $1000 \mathrm{cc}$. of saline, and $500 \mathrm{cc}$. of 5 per cent glucose, and by mouth $400 \mathrm{cc}$. of fluid with 1.5 gram of $\mathrm{NaCl}$ and 5 grams of sugar. During the second period of 8 hours she took $1600 \mathrm{cc}$. of fluid with 2 grams of $\mathrm{NaCl}$ and 95 grams of sugar.

Case 71956, a male 18 years old with diabetes of 4 years' duration, treated with insulin, had been in the hospital 2 years earlier in acidosis. After having neglected treatment for 2 months, on February 5, 1930, he developed a headache and next morning began to vomit. He was admitted at 7:00 P.M. February 6, semicomatose, dehydrated and overventilating, with a temperature of $98.6^{\circ} \mathrm{F}$., pulse 130 and blood pressure 140/100. He improved so rapidly under treatment that all symptoms of acidosis had disappeared within 12 hours. Subsequent recovery was uneventful except for a bronchitis, which had probably precipitated the acidosis. During the first period of 5 hours he received, subcutaneously, $500 \mathrm{cc}$. of 5 per cent glucose and $1500 \mathrm{cc}$. of saline, and by mouth $1300 \mathrm{cc}$. of fluid containing 30 grams of sugar and 2 grams of $\mathrm{NaCl}$. During the next period of 4 hours he took, by mouth, $800 \mathrm{cc}$. of fluid with 4 grams of $\mathrm{NaCl}$ and 20 grams of sugar. In the third period of 4 hours he took $400 \mathrm{cc}$. of fluid with 4 grams of $\mathrm{NaCl}$ and 10 grams of sugar. During the last period he received his regular diabetic diet and fluids were not recorded.

Case 48711, a girl of 14 , who had been treated for diabetes for several years and who had been in the hospital in acidosis on three previous occasions, in the early morning of October 8,1929, developed headache and sore throat and began to vomit. By 8:00 A.M. she was overventilating and had profuse glycosuria in spite of 10 units of insulin which had been given at 7:30. When admitted, at 10:00 A.M. she was extremely drowsy. Recovery was quite slow, although she was free from symptoms by the next morning. Because her 
condition did not seem precarious, in spite of nausea and inability to take fluids by mouth, she was given no hypodermic or intravenous fluids. Subsequent recovery was uneventful.

May 17, 1930, she failed to receive her full dose of insulin. The next morning her urine was free from sugar, but that night she began to vomit. Vomiting continued on the 19th in spite of 25 units of insulin given in divided doses during the morning and another 20 given at 1:30 P.M. The urine remained free from sugar until noon. At 3:00 P.M., overventilation began. She was admitted at 7:00 P.M., having received another 20 units of insulin at $5: 00$. Recovery was rapid and uneventful. In the first period of 4.5 hours she received only $100 \mathrm{cc}$. of fluid with 5 grams of sugar, because of vomiting. In the next 12 hours she took by mouth $1700 \mathrm{cc}$. of fluid with 1 gram of $\mathrm{NaCl}$ and 45 grams of sugar.

Case 72053, a female 53 years old, with diabetes of 8 years' duration, which had been treated by minimal dietetic restriction, developed an upper respiratory infection November 12, 1928 . November 24 she fell twice. On the same day increasing dyspnea, palpitation, abdominal pain and vomiting began. She was admitted at 5:00 P.M. on November 25, stuporous, thin, dehydrated, overventilating, with a distended bladder, a temperature of $95^{\circ} \mathrm{F}$., pulse 120 , and blood pressure 132/92. During the first 24 hours she vomited frequently and showed evidences of circulatory failure. At 11:00 P.M. she had paroxysmal auricular fibrillation, later changing to frequent premature beats. At 2:00 A.M. on November 26 the blood pressure had fallen to $94 / 62$, but after this she improved steadily and by morning was conscious and free from symptoms and signs of acidosis. In the first period of 6 hours she received, subcutaneously, $800 \mathrm{cc}$. of normal saline and $1000 \mathrm{cc}$. of 5 per cent glucose with an additional $800 \mathrm{cc}$. of fluid by mouth, much of which must have been vomited. In the second period she received, subcutaneously, $1500 \mathrm{cc}$. of saline and $500 \mathrm{cc}$. of 5 per cent glucose as well as $600 \mathrm{cc}$. of fluid by mouth, and vomited more than $900 \mathrm{cc}$.

Case 22074 , a male, 39 years old, with diabetes of 8 years' duration, had been under treatment with insulin for 6 years. January 9, 1929 he awoke with a cold; that evening he began to vomit and by the next morning was in deep coma. He was admitted to the hospital at 11:00 A.M. January 12 in profound coma, completely unresponsive, extremely dehydrated, pale, dusky, cold, overventilating, with râles over the right lower lobe, a temperature of $94.2^{\circ} \mathrm{F}$. and blood pressure 108/54. By 2:00 P.M. his color was better, his breathing quieter. He improved throughout the afternoon, although the coma persisted. At about 9:00 P.M. he had insulin shock, with profuse perspiration and falling blood pressure, which was relieved promptly by intravenous glucose. By 11:00 he could be roused and was able to take some broth by mouth. About midnight the respirations suddenly became gasping in character, profuse tracheal râles and extreme cyanosis appeared. The breathing became irregular and gradually slower until death at 1:30 A.M. Autopsy revealed lobar pneumonia. During the first period of 3.5 hours he received subcutaneously 1500 cc. of saline and $1500 \mathrm{cc}$. of 5 per cent glucose. During the second period of 10 hours he received intravenously $500 \mathrm{cc}$. of saline and $500 \mathrm{cc}$. of 5 per cent glucose besides two small doses of 50 per cent glucose; subcutaneously, $2000 \mathrm{cc}$. of saline and $500 \mathrm{cc}$. of 5 per cent glucose; and by mouth $450 \mathrm{cc}$. of fluid containing 2 grams of $\mathrm{NaCl}$ and 25 grams of sugar.

Case 81042 , a female 36 years old, with diabetes of 5 weeks' duration treated by diet alone, developed a sore throat September 17, 1929 . September 19 she vomited once. September 20 increasing drowsiness and air hunger 
began. She was admitted at 11:30 P.M. September 20, drowsy but not comatose, extremely emaciated and dehydrated, overventilating, with blood pressure $115 / 80$. Although she never appeared dangerously ill she remained somnolent for almost 48 hours, after which she recovered rapidly and uneventfully. Between 4:00 and 8:00 A.M. of July 21 her blood pressure fell to 98/60 and she showed signs of early shock. During the first period of 4.5 hours she received by mouth $2110 \mathrm{cc}$. of fluid containing 60 grams of sugar and 3 grams of $\mathrm{NaCl}$. During the next period of 4 hours she took $410 \mathrm{cc}$. of fluid with 23 grams of sugar. During the last period of 24.5 hours she took fluids freely, but the intake was not recorded.

Case 15670, a male 32 years old with diabetes of 7 to 9 years' duration, treated with insulin for 6 years, on September 26, 1929, was suddenly seized with weakness, lumbar pain, nausea, vomiting and increasing dyspnea. $\mathrm{He}$ was admitted at 4:00 A.M. September 27, quite conscious, overventilating, with a blood pressure of $160 / 90$, complaining of pain in the sides aggravated by breathing, with slight tenderness in the right flank. By 9:30 A.M. he was breathing more quietly, the pain was gone and he seemed improved. However, he looked exhausted to the point of collapse and his blood pressure was only $90 / 60$. The shock symptoms progressed until, by 11:00 P.M. the blood pressure had fallen to 79/55. With caffeine and intravenous 50 per cent glucose he rallied and by 2:00 P.M. the blood pressure was 112/74. Further recovery was somewhat delayed by an acute nephritis which was presumably the factor which had precipitated acidosis. During the first period of 5 hours he received subcutaneously $1000 \mathrm{cc}$. of saline and $500 \mathrm{cc}$. of 5 per cent glucose, and by mouth $950 \mathrm{cc}$. of fluid containing 55 grams of sugar and 10.5 grams of $\mathrm{NaCl}$. During the next 3 hours he took only $400 \mathrm{cc}$. of fluid with $1 \mathrm{gram}$ of $\mathrm{NaCl}$ and 30 grams of sugar. During the last period of 3 hours he took 230 cc. of fluid with 2 grams of $\mathrm{NaCl}$ and 25 grams of sugar.

Case A-11286, a female 24 years old, was admitted in deep coma at 4:00 P.M. January 31, 1932, extremely emaciated and dehydrated, overventilating, with a blood pressure of $110 / 80$, blood sugar $371 \mathrm{mgm}$. per $100 \mathrm{cc}$., serum bicarbonate $3.3 \mathrm{~m} . e q$. and proteins 6.87 per cent. She was given 3000 cc. of saline and 1000 cc. of 5 per cent glucose solution subcutaneously in the next 2 hours. Although the blood sugar at 5 P.M. had fallen to 276 there was no clinical improvement. At 7:30 the blood pressure was found to have fallen to 78/48. After an intravenous infusion of $1500 \mathrm{cc}$. of saline the blood pressure rose to about 100 . At the same time the patient roused from coma and began to toss restlessly in a mild delirium. Because the rise in blood pressure did not continue she was given a transfusion of $400 \mathrm{cc}$. of blood at 1:00 A.M. This had the immediate effect of raising the blood pressure to $116 / 76$ and further clearing the mental state. Although she remained stuporous and delirious for another 24 hours and the blood pressure fell again at intervals, the general condition was no longer a source of anxiety after the transfusion. The case was complicated by a neurological condition that may have been responsible for the prolonged stupor.

Case 60464, a male 30 years old, was admitted at 8:00 A.M. April 29, 1927, conscious and restless, but drowsy, emaciated and dehydrated, with marked air hunger, weak and rapid heart sounds, absent reflexes and cold extremities, a temperature of $96^{\circ} \mathrm{F}$. and blood pressure 96/70. At 10:40 A.M., because of the poor circulatory condition he was given an infusion of $1500 \mathrm{cc}$. of 5 per cent glucose. Shortly after this the blood pressure fell gradually to reach 70/50 by 1:00 P.M. At this time he was given a transfusion of $350 \mathrm{cc}$. of blood. Twenty minutes later his blood pressure was 106/80 and within an hour his 
respirations were quieter, he looked greatly improved and fell into a quiet sleep. His subsequent recovery was rapid and uneventful.

Case $A-700$, a female 60 years old, was admitted at 12 noon, December 31, 1931, well nourished but dehydrated, comatose, with cold skin, a temperature of $95^{\circ} \mathrm{F}$., slow weak pulse, blood sugar $1284 \mathrm{mgm}$. per $100 \mathrm{cc}$., bicarbonate 3.6 m.eq., serum proteins 7.78 per cent and blood pressure 100/58. She was given, subcutaneously, at once 40 units of insulin, $1500 \mathrm{cc}$. of saline and 500 cc. of 5 per cent glucose solution, and subsequently took some fluids by mouth. At 2:00 P.M. her blood pressure fell to 80 while the respirations became more rapid. She was immediately given by intravenous infusion $500 \mathrm{cc}$. of saline. Because the blood pressure rise provoked by the infusion was not well sustained she also received a transfusion of $250 \mathrm{cc}$. of blood at 8:30 P.M., but at this time her condition had already improved greatly and the blood pressure was 100/70. In the interval since admission the serum proteins had fallen to 7.38 per cent. After transfusion improvement was rapid and uneventful.

Case 82685, a female 65 years old, was admitted at 5:00 P.M. March 4, 1930, semicomatose, extremely dehydrated, overventilating, with faint heart sounds, a temperature of $100^{\circ} \mathrm{F}$., pulse 140 and blood pressure $100 / 85$. At 7:00 P.M. she received, subcutaneously, $500 \mathrm{cc}$. of 5 per cent glucose solution and 2500 cc. of saline which seemed to cause temporary improvement, but at noon she was more comatose, her blood pressure had fallen to $90 / 65$, and her pulse was weak, rapid and irregular. A transfusion of $250 \mathrm{cc}$. of blood at 2:00 P.M. brought the blood pressure up to 120/50 and caused temporary improvement, but the blood pressure soon fell again further than ever, and she sank deeper into coma. Although she lived until the early morning of March 6 shock symptoms and coma persisted in spite of all measures which were taken to combat them. Although the clinical course was so unfavorable, the blood sugar, bicarbonate and ketonuria responded rapidly to treatment. In the first 5 hours the blood sugar fell from 667 to $368 \mathrm{mgm}$. per $100 \mathrm{cc}$., the bicarbonate rose from 9.2 to 15.5 m.eq., and ketonuria diminished from a $4+$ to a $1+$ reaction. Serum proteins, however, rose from 7.28 to 7.43 per cent. In the next period of 11 hours, when the systolic blood pressure fell to 50 , the serum proteins dropped to $\mathbf{5 . 9 6}$ per cent.

\section{BIBLIOGRAPHY}

1. Peters, J. P., Bulger, H. A., and Eisenman, A. J., J. Clin. Invest., 1925, i, 451. The Plasma Proteins in Relation to Blood Hydration. II. In Diabetes Mellitus.

2. Bulger, H. A., Peters, J. P., Lee, C., and Murphy, C. F., Arch. Int. Med., 1925, xxxvi, 857. The Concentration of the Blood and of the Urine in Diabetic Toxemia.

3. Widal, F., Abrami, P., Weill, A., and Laudat, Presse Méd., 1924, xxxii, 565. L'hydrémie au cours du diabète traité par l'insuline variations de l'indice réfractométrique du sérum.

4. Chang, H. C., Harrop, G. A., Jr., and Schaub, B. M., J. Clin. Invest., 1927-28, v, 407. The Circulating Blood Volume in Diabetic Acidosis.

5. Peters, J. P., Wakeman, A. M., Eisenman, A. J., and Lee, C., J. Clin. Invest., 1929, vi, 517. Total Acid-base Equilibrium of Plasma in Health and Disease. X. The Acidosis of Nephritis.

6. Bruckman, F. S., D'Esopo, L. M., and Peters, J. P., J. Clin. Invest., 1930, viii, 577. The Plasma Proteins in Relation to Blood Hydration. IV. Malnutrition and the Serum Proteins. 
7. Bruckman, F. S., and Peters, J. P., J. Clin. Invest., 1930, viii, 591. The Plasma Proteins in Relation to Blood Hydration. V. Serum Proteins and Malnutritional or Cachectic Edema.

8. Weech, A. A., and Ling, S. M., J. Clin. Invest., 1931, x, 869. Nutritional Edema. Observations on the Relation of the Serum Proteins to the Occurrence of Edema and to the Effect of Certain Inorganic Salts.

9. Blalock, A., Beard, J. W., and Johnson, G. S., J. A. M. A., 1931, xcvii, 1794. Experimental Shock. A Study of its Production and Treatment.

10. Peters, J. P., Wakeman, A. M., Eisenman, A. J., and Lee, C., J. Clin. Invest., 1929, vi, 577. Total Acid-base Equilibrium of Plasma in Health and Disease. XII. A Study of Renal Edema.

11. Henderson, Y., and Haggard, H. W., J. Biol. Chem., 1918, xxxiii, 355. Respiratory Regulation of the $\mathrm{CO}_{2}$ Capacity of the Blood. III. The Effects of Excessive Pulmonary Ventilation.

12. de Almeida, A. O., and de Almeida, M. O., J. A. M. A., 1918, lxxi, 1710. The Nature of Surgical Shock and Henderson's Theory of Acapnia.

13. Dale, H. H., and Evans, C. L., J. Physiol., 1922, lvi, 125. Effects on the Circulation of Changes in the Carbon Dioxide Content of the Blood.

14. Lawrence, R. D., Brit. M. J., 1930, i, 690. The Treatment of Desperate Cases of Diabetic Coma. 